\title{
Revision of the Gault foraminifera from the Hollis and Neaverson Collection (1921)
}

\author{
C. HERREROI \& J. R. HAYNES ${ }^{2}$ \\ ${ }^{1}$ Departamento de Paleontología, Facultad de Ciencias Geológicas, Universidad Complutense de Madrid, Ciudad Universitaria, \\ 28040 Madrid, Spain. \\ ${ }^{2}$ Geology Department, Institute of Earth Studies, University of Wales, Aberystwyth, Dyfed SY23 3DB, UK.
}

\begin{abstract}
In 1921, Hollis and Neaverson listed 135 species and varieties of foraminifera from the Gault Phosphatic Nodule Bed at Ford, Buckinghamshire, England. The material has been re-examined, the list is brought up to date and the species are figured. The Collection has yielded a diverse and well preserved foraminiferal fauna of 90 species. Nodosariacea are the dominant group, though Ataxophragmiacea, Hedbergellacea and Miliolacea are abundant. The recorded assemblages allow us to date the Phosphatic Nodule Bed at Ford as belonging to the uppermost Euhoplites lautus Zone to lower part of Mortoniceras inflatum Zone within the Albian standard ammonite zonation. J. Micropalaeontol. 16(1): 73-84, May 1997.
\end{abstract}

\section{INTRODUCTION}

Hollis and Neaverson (1921) published a short paper on the Gault foraminifera from the workings for phosphatic nodules at Ford, four miles southwest of Aylesbury, Buckinghamshire (England). They listed 135 species and varieties of foraminifera but neither descriptions nor illustrations were given by the authors. After their paper no other workers have given additional information about the foraminifera of the Gault at Ford. In fact, no references to the paper of Hollis and Neaverson (1921) have been found in the Early Cretaceous literature of Great Britain except for one by Crittenden (1988: p. 19, Unpublished Ph.D. Thesis, Plymouth Polytechnic).

The location of the site in which the Gault was worked at
Ford for phosphatic nodules is not known exactly. In their paper, Hollis and Neaverson (1921) commented that the workings from which Hollis had collected his material in 1919 were abandoned and nothing remained but the spoil-heap which was by then (1921) completely grassed over. The available information, about the fields where the workings are said to have been (Fig. 1), was provided by the locals or elderiy relatives of the locals to the Buckinghamshire County Museum (pers. comm. Ms K. M. Hawkins, Keeper of Biology and Geology of that Museum).

The only description of the nodules beds is that of Keeping, who saw earlier workings near Ford in 1876. According to Jukes-Brown, who incorporated his observations into his

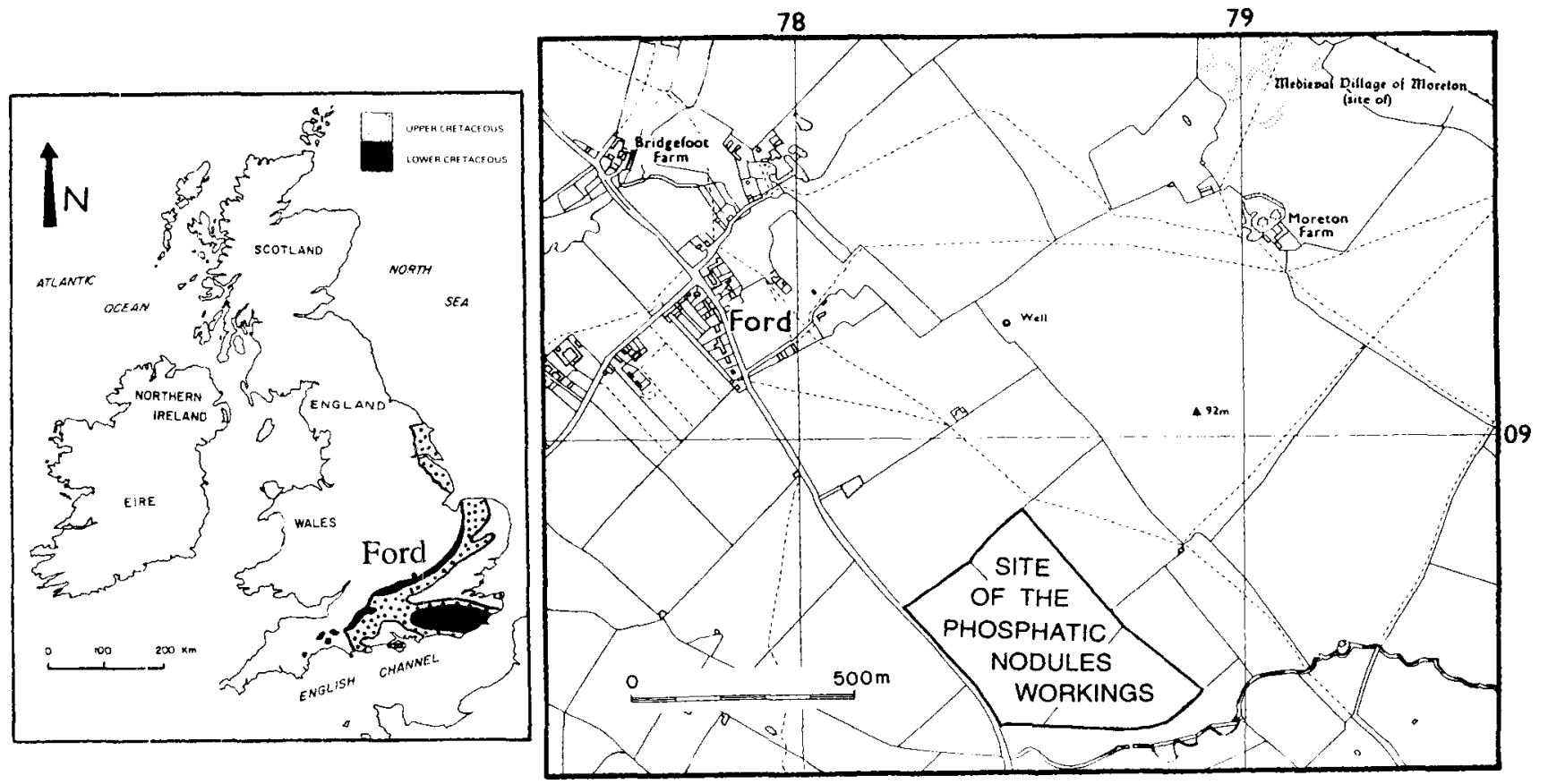

Fig. 1. Cretaceous outcrops in southern Britain and location of the site of phosphatic nodules ('coprolites') workings, modified from sheet SP 70 NE (by courtesy of Ms K. M. Hawkins, Buckinghamshire County Museum, Aylesbury). 
memoir (1900), the nodules were worked on this occasion between the years 1875 and 1884 . Keeping's remarks include the following:

The coprolite seam is 3 to 4 inches thick and is constant throughout the pit, though the bed is irregular in position. The irregularity is of two kinds, the commonest being slips of a few inches ( 4 to 10), cutting off the seam with a clear face marked by slickensides; in other cases the bed is bent downwards to a similar extent, and this bending is due, I am inclined to think, to subsequent folding and not to irregularity of deposition.

The matrix of the seam is a stiff calcareous clay crowded with phosphatised shells and lumps of 'coprolite' which in my cursory search, I could not prove to have suffered from erosion previous to being embedded in the Gault, while some of them, such as Hamites were in such a condition that they could not have sustained much knocking about on a shore.

Above the [nodule] bed comes a hard clay with iron-stained joint planes, which is covered by a true clay, somewhat lighter in colour than ordinary Gault, and containing a second irregular coprolite zone in a series of lenticular patches. Its nodules are smaller than in the regular seam below.

It should be noted that the emphasis on structural relationships in this account may be explained by the fact that Keeping was teaching geology at Aberystwyth at this time and attempting to work out the structure of Plynlimmon!

Jukes-Brown visited the workings in 1885 after they had been abandoned but was able to collect fossils. Collections were also made by a local schoolmaster (Mr Hayter of Monks Risborough) which put together with those of Keeping presented a 'curious assemblage for the Lower Gault', including 'Ammonites' auritus, cristatus and lautus.

Hollis and Neaverson in their remarks on the ammonites said,

Judging by specimens of ammonites in the Bucks. County Museum, Aylesbury, the deposit worked belonged to the zones of Hoplites auritus and $H$. lautus. At the typical locality of Folkestone, these zones occupy 17 feet out of a total of 99 feet for the whole of the Gault; but at Ford only three or four feet seem to have been worked. Critical zonal study is, of course, impossible; ...

We were pleasantly surprised to discover that there were three different sets of slides of the Hollis and Neaverson Collection of the Gault at Ford. One set is located in the Buckinghamshire County Museum (Aylesbury, England), the other one in the Natural History Museum (London, England) and the last one in the Micropalaeontological Museum of the University of Wales (Aberystwyth, Wales). The first two sets in the Museums were donated by $E$. Hollis while the third one was eventually deposited at Aberystwyth when acquired by Prof. A. Wood from Neaverson who had been his research supervisor at Liverpool University.

The aim of this work is to bring up to date the list of foraminifera of the Hollis and Neaverson paper, document the three scattered collections of slides and their contents and illustrate all the species, which are mostly represented by very well preserved specimens. On this basis we will attempt to relate the fauna to the modern, foraminiferal biostratigraphy of the
Gault, foraminiferal ranges now being regarded as somewhat more 'critical' than in the time of Hollis and Neaverson who were under the heavy influence of Chapman and the 'English School'.

\section{MATERIAL}

The state and characteristics of the collections are described below.

\section{Buckinghamshire County Museum (Aylesbury)}

The set consists of slides made of cedar-wood, originally without cover-glasses (covered in the course of this study). The accession register, number 38 , dates from 29 January 1920, and to quote from it, describes the collection as consisting of ' 108 microscope slides, foraminifera from Gault, Ford, Bucks., collected by Hollis 1919'. They are well set out and labelled but the information on them is limited. The labels are arranged in horizontal orientation and comprise on the left side the generic and/or specific identification and the locality and unit (Gault, Ford, Bucks.) and on the right side the specific classification, or nothing. On the back of the slides is written ' $\mathrm{E}$. Hollis 1919' and the slide number (see Tables 1 \& 2). As it now stands, the collection includes 124 slides (Trays 38:20). Of them, 17 slides contain specimens as yet unidentified (perhaps not originally registered) and 107 slides with identified specimens. Of the 107, four have specimens with only generic classification [Nodosaria (two slides), Pleurostomella (one slide) and Pulvinulina (one slide)], two have specimens left in open nomenclature (Nodosaria sp.) and 101 have specimens with specific identification. Of all the species and varieties that are identified on the slides, 106 are included in Hollis and Neaverson's list published in 1921 and 28 are not included. In addition, there are 29 species on the list which were not found in the slides (see Tables $1 \& 2$ ).

\section{Natural History Museum (London)}

As in the Aylesbury collection the slides are made of cedar-wood and without cover-glasses. The labels are arranged in the same way. The only difference is that there are no labels on the back of the slides. The accession register indicates that the material was deposited by E. Hollis in 1926 and the register numbers are from P23018 to P23232 (Tray Q94). All the slides have specific identification and of those, 56 are included in the published list of Hollis and Neaverson, 10 are not in it and 79 species and varieties of the list were not found in the slides (see Tables 1 \& 2).

\section{Micropalaeontological Museum, University of Wales (Aberyst- wyth)}

This last set consists of 47 slides, also made of cedar-wood, originally without cover-glasses and now with them, attached in the course of this work. The labels on the slides are arranged in vertical orientation. The label includes at the top the following items: 'Foraminifera, Gault, Ford, Bucks., Aug. 1919, Eng.'. The generic and specific identification is written down in ink or in pencil at the bottom of the label. The accession number is JH.389 and now all the slides have been numbered (see Tables 1 $\& 2$ ). Two of the slides contain specimens as yet unidentified, another two with only generic classification (Bulimina and Nodosaria) and 43 with specific identification. Of all the species 


\begin{tabular}{|c|c|c|c|c|}
\hline & & \begin{tabular}{|c|} 
B C M \\
Slide \\
number \\
\end{tabular} & $\begin{array}{l}\text { N H M } \\
\text { Register } \\
\text { number }\end{array}$ & $\begin{array}{c}\mathbf{M} \mathbf{M} \\
(\mathbf{U} \mathbf{W} \mathbf{A}) \\
\text { Slide no. }\end{array}$ \\
\hline & Nubec ullurio nodulosa Chapman & 2 & P23035-23038 & 1 \\
\hline & Sproroloculina nitida d'Orbigny & 7 & $\mathrm{P} 230404-23053$ & 2 \\
\hline & Mitiolina venusta (Karrer) & 8.10 & $P 23025-23034 \mid$ & 3 \\
\hline & Miliolina tricarinata (d'Orbigny) & 9 & P23022-23024 & 3 \\
\hline & Mitholina ferussactii (d'Orbigny) & 10 & P23224-23226 & 3 \\
\hline & Reophax scorpiurus Montfort & 11 & P23207-23209 & 4 \\
\hline & Haplestragmium aruidorsatum Hantken & 12 & $P 23200-23203$ & 5 \\
\hline & Haplophragmium globigeriniforme (P.\& J.) & 130 & - & _- \\
\hline & Haplowtiche sherborni Chapman & 15 & P23204-23206 & 6 \\
\hline 10) & Thurammina alhicans Brady & 16 & P23189-23192 & - \\
\hline ii) & Ammodiscur incertus (d'Orbigny) & 5,6 & $\mathrm{P} 23097$ & 7 \\
\hline 12. & Ammodiscus millettianus Chapman & - & - & 70 \\
\hline 13 & Textuluria minuta Berthelin & 22 & - & 80 \\
\hline 14 & Textularia trochus d' Orbigny & 23 & _- & 9 \\
\hline 15 & Textuluria turrus d'Osbigny & 23 & P23164-23169 & 9 \\
\hline 16 & Textularia conica d'Orbigny & 23 & - & 8 \\
\hline 17 & Textularia agglutinans d'Orbigny & 24 & - & 30 \\
\hline 18. & Textularia praelonga Reuss & 22 & - & $8(2)$ \\
\hline [9] & Textularia complanata (Reuss) & 20 & P23173-23176 & 11 \\
\hline 20 & Verneuilina triquetra (Münster) & 25 & P23161-23163 & 12 \\
\hline 21) & Tritaxia tricarinata Reuss & - & - & 130 \\
\hline 22 & Trituxia pyramidata Reuss & 25 & P23158-23160 & - \\
\hline 23. & Spiroplecta unnectens (Parker \& Jones) & - & - & 140 \\
\hline 24 & Spiroplecta complanata (Reuss) & $20-22$ & P23177-23188 & 14 \\
\hline 25 & Gaudryina rugasa d'Orbigny & 24 & - & - \\
\hline 26 & Gaudnina oxycona Reuss & - & - & _- \\
\hline 27) & Bulimina orbignyi Reuss & $26-28$ & P23153-23156 & 15 \\
\hline 28 & Bulimina murchisoniana d'Orbigny & 27 & - & - \\
\hline 29 & Bulimina obtusa d'Orbigny & 28 & - & - \\
\hline 30) & Butimina brevis d'Ontigny & 28 & - & - \\
\hline 31] & Bulimina affinis d'Orbigny & 27 & - & - \\
\hline 32 & Pleurostomella obtusa Berthelin & 29 & P23145.23147 & 16 \\
\hline 33 & Pleurostomella atternans Schwager & 29 & P23148-23149 & 16 \\
\hline 34$]$ & Lagena globosa (Montague) & - & - & 170 \\
\hline 35 & Lagena ariculata Reuss & 31 & P23142-23144 & - \\
\hline 36 & Lagena apiculata var emaciata Reuss & 34 & - & $17(2)$ \\
\hline 37) & Lagena gracillima (Seguenza) & 33 & - & - \\
\hline 38 & Lagena hispida Reuss & 32 & P23140-23141 & - \\
\hline 39 & Nodosaria (G.) humilis Römer & 45 & P23116-23118 & 18 \\
\hline 40 & Nodosaria (G) mutabilis $(\mathrm{R}$ & 43 & P23112-23115 & 18 \\
\hline 41 & Nodosurivi (G.) cylindracea Reuss & 44 & - & - \\
\hline 42 & Nodosaria radicula (L.) var jonesi Ret & - & - & 18 \\
\hline 43 & Nodosario (D.) farcimen (Soldani) Reuss & 48 & $\ldots$ & 19 \\
\hline 44 & Nodosarici (D.) soluta (Reuss) & 41 (3) & P23107-23108 & - \\
\hline 45 & Nodosaria (D.) soluta var. pulc & 410 & - & - \\
\hline 46. & Nodosuria (D) gracilis (d'Orbign) & 48 & - & - \\
\hline 47) & Nodosaria $(D$ ) forneiana (d'Orbigny & 48 & - & 20) \\
\hline 48 & Nodosaria (D.) paupe rata (d'Orbign & 52 & P23105-23106 & - \\
\hline 49 & Nodossria (D.) consobrina (d'Orbigny) & 50 & P23136 & - \\
\hline 50 & Nodosaria (D) fylindroides (Reuss) & - & - & 20 \\
\hline 51 & Nodosaria $(D$. ) hamulifera Reuss & 47 & - & - \\
\hline 52 & Nodosidria (D.) xiphioides Reuss & 52 & P23109-23110 & 20 \\
\hline 53 & Nodosaria (D.) legumen & 49 & P23122-23123 & 19 \\
\hline 54] & Nodosaria (D.) romemeri (Neugeboren) & 46 & P23104 & 20 \\
\hline 55 & Nodosaria $\{$ D. f communis d'Orbig & _- & - & 20 \\
\hline 56. & Nodosaria D.) mucronata (Neugeboren) & $37(3)$ & P23127 (3) & 190 \\
\hline 57 & Nodosaria D I raristriata Chapman & - & - & 19 \\
\hline 58 & Nodosaria alomontha Reuss & 38 & $\mathrm{P} 23103$ (4) & - \\
\hline 59 & Nodosaria hispida d'Orbigny & 42 & - & 21 \\
\hline 60) & Nodosaria bumbusa Chapman & 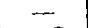 & - & 21 (2) \\
\hline 61 & Nodosaria (D.) intercellularis Brady & 40) (3) & - & - \\
\hline 62 & Nodosaria sceptrum Reuss & 43 & - & 22 \\
\hline 63 & Nodosaria (D.) paupercula Reuss & $39-40(3)$ & P23101 & 21,220 \\
\hline 64 & Nodoraria (D.) fontannesi (Berthelin) & 37. A & P23119-23121 & $21 \otimes 0$ \\
\hline 65 & Nodosaria (D) obscura Reuss & 40,51 & $|\mathrm{P} 23137-23139|$ & 22 (1) \\
\hline 66 & Nodosaria (D.) ienuicoste Reuss & 35 (3) & P23124-26(3) & - \\
\hline 67. & Nodosaria prismatica Reuss & - & & 22 \\
\hline 68 & Nodosaria orthopleura Reuss & 36 & P23130-23135 & 21 \\
\hline
\end{tabular}

\begin{tabular}{|c|c|c|c|c|}
\hline & & $\begin{array}{c}\text { B C M } \\
\text { Stide } \\
\text { number }\end{array}$ & $\begin{array}{l}\mathbf{N ~ H ~ M} \\
\text { Register } \\
\text { number } \\
\end{array}$ & $\begin{array}{c}\text { MM } \\
\left(\begin{array}{l}\text { U W A } \\
\text { Slide no }\end{array}\right. \\
\end{array}$ \\
\hline 69 & Nedosaria tetragona Reuss & 40 & 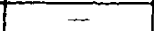 & 22 \\
\hline 70 & Lingulina nodosaria Reuss & 58 & -_ & - \\
\hline 71 & Lingulina semiornata Reuss & 57 & - & 23 \\
\hline 72 & Frondicularia loryi Berthelin & 60 & P23099 & 24 \\
\hline 73 & Frondicularia densiculocarinata Chapman & 60 & P23098 & $25(2)$ \\
\hline 74 & Frondicularia gaultina Reuss & 61 & - & _- \\
\hline 75 & Frondicularia frisschi Perner & 59 & P23217-23221 & 26 \\
\hline 76 & Frondicularia cf, strigillata Reuss & - & - & 260 \\
\hline 77 & Frondicularia ungeri Reuss & 61 & - & 26 \\
\hline 78 & Frondicularia parkeri Reuss & $62-63$ & - & 26 \\
\hline 79 & Frondicularia planifolia Chapman & 61 & - & 24 \\
\hline 80 & Frondicularia guestphalica Reuss & 63 & P23210-23216 & 24 \\
\hline 81 & Frondicularia microdisca Reuss & $\ldots$ & - & 25 \\
\hline 82 & Frondicularia perovata Chapman & - & - & 24 \\
\hline 83 & Frondicularia cordai Reuss & 63 & - & 24 \\
\hline 84 & Rhabdogonium tricarinatum (d'Orbigny) & $66(5)$ & P23151(5-52 & - \\
\hline 85 & Rhabdogonium excavatum Reuss & 66 & P23150 & 27 \\
\hline 86 & Marginulina glabra d'Otbigny & - & - & 28 \\
\hline 87 & Marginulina indequalis Reuss & - & - & 282 \\
\hline 88 & Marginulina linearis Reuss & 70 & $\mathrm{P} 23062$ & 28 \\
\hline 89 & Marginulina debilis Berthelin & 67 & - & 280 \\
\hline 90 & Marginulina aequivoca Reuss & 71 & - & - \\
\hline 91 & Marginulina striatecostata Reuss & 68 & - & 28 \\
\hline 92 & Marginulina jonesi Reuss & 71 & P23063-23064 & 28 \\
\hline 93 & Vaginulina recta Reuss & 74 & P23077-23086 & 29 \\
\hline 94 & Vaginulina strigillata (Reuss) & 78 & P23040-23042 & 30 \\
\hline 95 & Vaginulina truncata Reuss & 72 & P23088-23092 & 29 \\
\hline 96 & Vaginulina gaultina Berthelin & 77 & $\mathrm{P} 23018$ & 30 \\
\hline 97 & Vaginulina hiochei Berthelin & 76 & - & - \\
\hline 98 & Vaginulina priceana Chapman & 75 & - & 30)(2) \\
\hline 99 & Cristellaria exilis Reuss & 92 & - & 31 \\
\hline 100 & Cristellaria parallela Reuss & 94 & - & $32(2)$ \\
\hline 101 & Cristellaria humilis Reuss & 93 & - & 33 \\
\hline 102 & Cristellaria crepidula (Fitchel \& Moll) & 97 & - & - \\
\hline 103 & Cristellaria navicula d'Orbigny & - & - & 31 \\
\hline 104 & Cristellaric sulcifera Reuss & 88 & - & 32 (2) \\
\hline 105 & Cristeflaria triangularis d'Orbigny & - & - & 31 \\
\hline 106 & Cristellaria trunculata Berthelin & - & - & 33 \\
\hline 107 & Cristellaria scitula Berthelin & - & - & 320 \\
\hline 108 & Cristellaria bononiensis Berthelin & - & - & 33 \\
\hline 109 & Cristellaria itatica (Defrance) & 91 & - & 31 \\
\hline 110 & Cristellaria vestita Berthelin & 97 & $|\mathrm{P} 23057-23060|$ & 33 \\
\hline 111 & Cristellaria complanata Reuss & 97 & P23061 & 32 (2) \\
\hline 112 & Cristellaria bradyana Chapman & - & - & 32 (2) \\
\hline 113 & Cristellaria turgidula Reuss & 87 & $P 23065-23069$ & 34 \\
\hline 114 & Cristellaria circumcidanea Berthelin & - & - & 35 (2) \\
\hline 115 & Cristellaria lobata (Costa) & - & - & $35(2)$ \\
\hline 116 & Cristellaria gibba d'Orbigny & 91 & - & $35(2)$ \\
\hline 117 & Cristellaria convergens Bornemann & 86 & - & - \\
\hline 118 & Cristellaria rotulata (Lamarck) & 85 & P23070-23076 & 34 \\
\hline 119 & Cristellaria rotulata var. macrodiscus Reuss & - & - & 360 \\
\hline 120 & Cristellaria gaultina Berthelin & $95-96$ & P23019-23021 & 35 \\
\hline 121 & Cristellaria sternalis Berthelin & - & - & 34 \\
\hline 122 & Cristellaria diademata Berthelin & 89 & - & $34(2)$ \\
\hline 123 & Polymorphina lactea var. acuplacenta (J.\& C.) & - & - & - \\
\hline 124 & Polymorphina fusiformis (Römer) & 79,81 & - & 37 \\
\hline 125 & Polymorphina fusiformis var. horrida Reuss & & - & - \\
\hline 126 & Sagrina asperula Chapman & 82 & $\ldots$ & $38(2)$ \\
\hline 127 & Sagrina calcarata (Berthelin) & 82 & $\ldots$ & 38 (2) \\
\hline 128 & Ramulina globulifera Brady & 98 & - & 39 \\
\hline 129 & Ramulina aculeata Wright & 98 & - & 39 \\
\hline 130 & Globigerina cretacea d'Orbigny & 100 & P23054-23056 & 40 \\
\hline 131 & Discorbina rugasa (d'Orbigny) & 101 & P23222-23223 & - \\
\hline 132 & Anomalina ammonoides (Reuss) & 103 & P23227-23229 & 41 \\
\hline 133 & Putvinutina eleguns (d'Orbigny) & - & - & $42(2)$ \\
\hline 134 & Pulvinulina caracolla (Römer) & 106 & P23198-23199| & 42 (2) \\
\hline$[35$ & Pulvinutina spinutifera (Reuss) & 104 & - & 43 \\
\hline
\end{tabular}

Table 1. Original published list of Hollis \& Neaverson (1921) and location of the material in the three museums. BCM: Buckinghamshire County Museum (Aylesbury); NHM: The Natural History Museum (London); MM (UWA): Micropalacontological Museum, University of Wales (Aberystwyth). (1), empty slide; (2), the specific identification is written in pencil; (3), the specific name is written without the sub-genus (Dentalina) on slide and/or register book; (4), the specific name is written with the sub-genus (Dentalina) in the register book; (5), the variety 'acutangulum' Reuss is written on slide and/or register book; (6), Cristellaria macrodisca (Reuss) is written on the slide. 


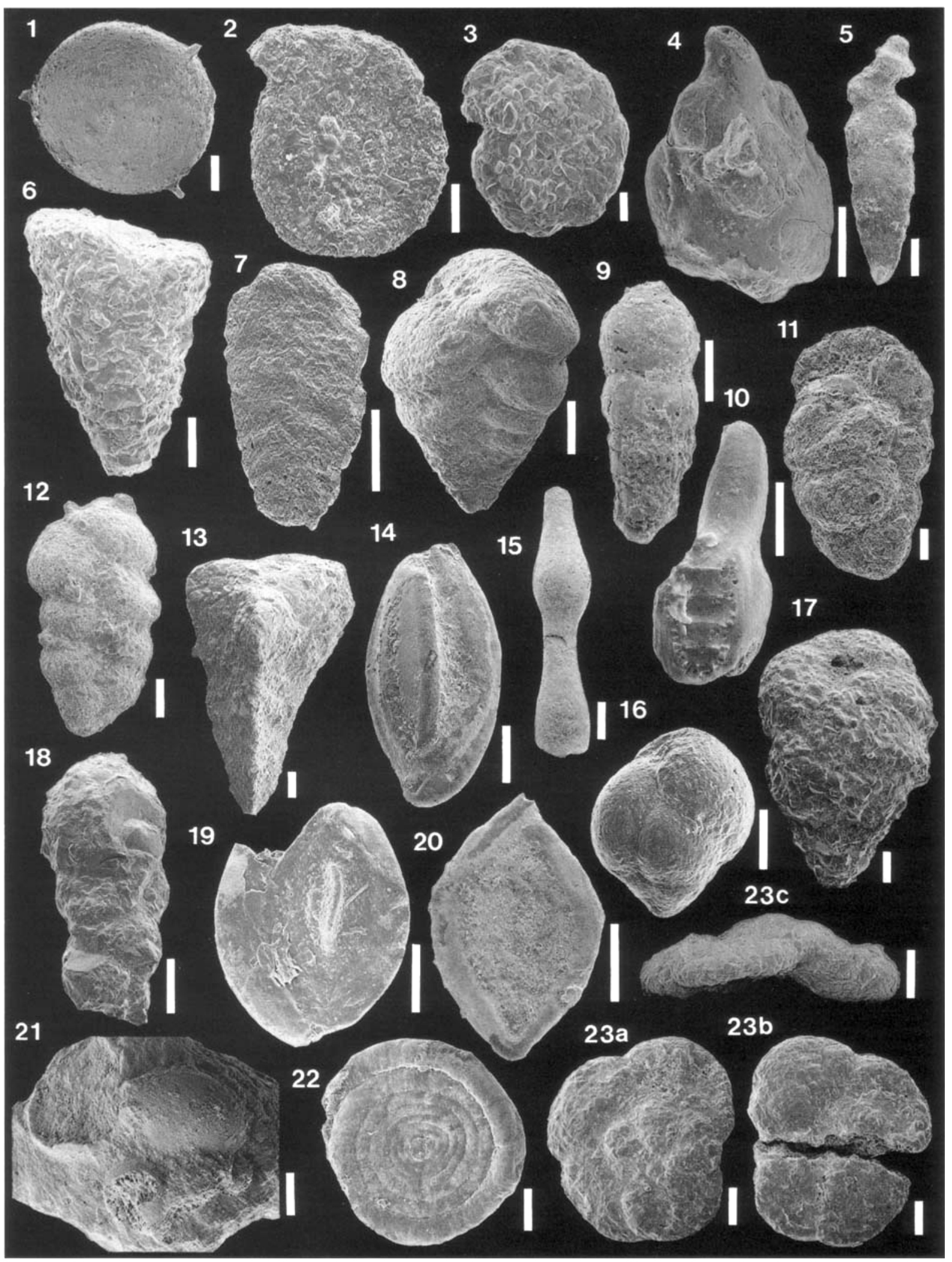

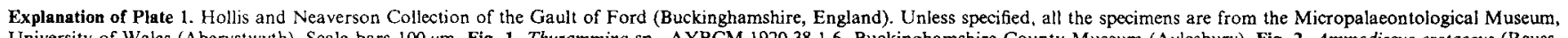

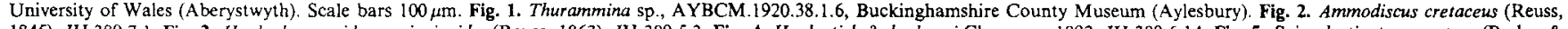

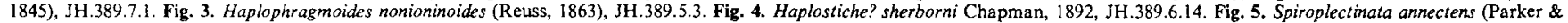
Jones, 1863), JH.389.14.12. Fig, 6. Dorothia turris (d' Orbigny, 1840), JH.389.9.8. Fig. 7. Textularia minuta Berthelin, 1880, JH.389.8.6. Fig, 8. Textularia chapmani Lalicker, 1935, JH.389.8.5.

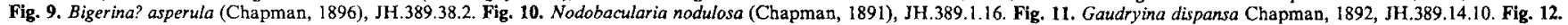

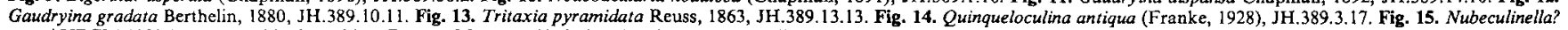
sp., AYBCM.1920.38.3.1, Buckinghamshire County Museum (Aylesbury). Fig. 16. Eggerellina mariae Ten Dam, 1950, JH.389.9.9. Fig. 17. Arenobulimina chapmani Cushman, 1936,

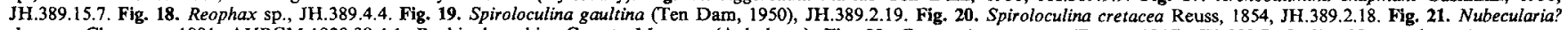
depressa Chapman, 1891, AYBCM.1920.38.4.1, Buckinghamshire County Museum (Aylesbury). Fig. 22. Cornuspira cretacea (Reuss, 1845), JH.389.7.15. Fig. 23. Trochammina concava Chapman, 1892, AYBCM.1920.38.18.1, Buckinghamshire, County Museum (Aylesbury), (a) dorsal view, (b) ventral view, (c) lateral view. 


\begin{tabular}{|c|c|c|c|c|}
\hline & & $\begin{array}{c}\mathbf{B C M} \\
\text { Slide } \\
\text { number }\end{array}$ & $\begin{array}{l}\text { N H M } \\
\text { Register } \\
\text { number }\end{array}$ & $\begin{array}{c}\text { M M } \\
\text { (U W } \\
\text { Slide no. }\end{array}$ \\
\hline & Anomalina rudis (Reuss) & 102 & & \\
\hline & Clavulina angularis d'Otbigny & 19 & - & - \\
\hline & Crissellaria latifrons Brady & 97 & P23128-23129 & - \\
\hline & Cristellaria linearis Reuss & 84 & - & - \\
\hline & Cristellaria mamilligera Karrer & 90 & - & - \\
\hline & Cristellaria tripleura Reuss & 97 & - & - \\
\hline & Flabellina didyma (Berthelin) & 65 & P23087 & - \\
\hline & Frondicularia didyma Berthelin & - & -_- & 26 \\
\hline & Globigerina aequilateralis Brady & 99 & - & - \\
\hline & Haplophagmium nonioninoides Reuss & 14 & P23111 & - \\
\hline & Marginulina folkenstoniensis Chapman & 69 & - & - \\
\hline 12) & Nodosaria inflata Reuss & 40 & - & -_ \\
\hline 13 & Nodosaria (G.) laevigata d'Orbigny & 38 & P23102 & - \\
\hline 14 & Nubecularia depressa Chapman & 4 & - & - \\
\hline & Nubecularia tibia (Jones \& Parker) & 3 & - & - \\
\hline 16 & Polymorphina angusta Egger & 79 & - & - \\
\hline & Polymorphina cominunis d'Orbigny & 80 & - & - \\
\hline 18 & Polymorphina compressa d'Orbigny & 79 & - & -- \\
\hline & Polymorphina gibba d'Orbigny & 81 & - & - \\
\hline & Polymorphina lactea (Walker) & 81 & - & - \\
\hline 21 & Polymorphina sosoria Reuss & 81 & - & - \\
\hline & Polymorphina sosoria var. cuspidata Brady & 80 & - & \\
\hline 23 & Pulvinulina reticulata Reuss & 105 & P23157 & 42 (1) \\
\hline & Spiroloculina asperula Karrer & - & - & 2 (1) \\
\hline 25 & Textularia gramen d'Orbigny & 24 & P23170-23172 & - \\
\hline & Thurammina papillata Brady & 17 & P23193-23197 & - \\
\hline 27 & Trochammina concava Chapman & 18 & $\mathrm{P} 23100$ & - \\
\hline & Vaginulina arguta Reuss & 77 & P23039 & - \\
\hline & Vaginulina recta var. tenuistriata Chapman & 77 & - & - \\
\hline & Vaginulina truncata var. robusta B. \& C. & 73 & P23093-23096 & - \\
\hline
\end{tabular}

Table 2. List of species found in the slides and not included in the published list of Hollis and Neaverson (1921). (1), the specific identification is written in pencil.

and varieties, 103 (75 written in ink and 28 in pencil) are included in the list of Hollis and Neaverson, three are not in it and 32 specific names on the list were not found in the slides (see Tables 1 \& 2).

Combining the three sets of slides, 1311 specimens of foraminifera of the Gault at Ford have been examined (423 from the Buckinghamshire County Museum, 214 from the Natural History Museum and 674 from the Micropalaeontological Museum of the University of Wales). Specimens of two species and two varieties of the original published list of Hollis and Neaverson [Haplophragmium globigeriniforme (Parker \& Jones), Gaudryina oxycona Reuss, Polymorphina fusiformis Roemer var horrida Reuss and Polymorphina lactea (Walker \& Jacobs) var. acuplacenta (J. \& C.)] are not in either of the three sets (see Table 1), so unfortunately they could not be included in this work.

\section{RESULTS}

In bringing up-to-date the list of species names used by Hollis and Neaverson for the Foraminifera of the Gault (see Table 1), it has been necessary to change most of the generic names and a number of specific names as well. In part this simply reflects progress in taxonomic discrimination but also the tendency of the members of the 'English School', such as Chapman, to apply Recent names to fossil species. However, in his work on the Gault, Chapman (1891-1898) recognized many new species and accepted many set up by Continental authors. Interestingly, this preceded the disastrous 'discovery' of the supposed Cambrian foraminifera of the Malverns in 1900 which seemed to confirm all the prejudices of the 'English School'.
In Table 3, the updated names used in this work are in the left column and are arranged following the foraminiferal classification of Haynes (1981). The right column includes the equivalencies of the list of Hollis and Neaverson (1921). The species with an asterisk are those that are not included in the published list but were found in the slides. The 'p.p.' for some species is explained at the end of the table.

The agglutinated foraminifera are represented by two species of the Order Astrorhizida and 14 of the Order Lituolida. Of them, two species, Thurammina sp. and Reophax sp., have been left in open nomenclature and another, Bigerina? asperula (Chapman), with doubtful generic identification due to the bad preservation of the initial portion of the test in all the examined specimens. In addition, Sagrina calcarata (Berthelin) although on the list could not be identified because it is represented in the slide by two indeterminate fragments of agglutinated foraminifera only. The species Ammodiscus millettianus Chapman was misindentified by Hollis and Neaverson (1921) as in the slide there are only four fragments of organic carbonates.

The porcelaneous foraminifera, Order Miliolida, are represented by a significant number of specimens belonging to seven species. One of them, Nubecularia? depressa Chapman has been left with doubtful generic identification as it is not possible to see the initial portion of the test in the specimen of the collection. The specimen that Hollis and Neaverson named Nubecularia tibia (Parker \& Jones) has been left in open nomenclature as only the last two free chambers are preserved.

The Order Nodosariida is the best, well-represented group. Sixty species have been identified (50 of the Superfamily Nodosariacea, three of the Superfamily Polymorphinacea and seven of the genus Ramulina). The specimens of Lingulina nodosaria Reuss, Nodosaria (Dentalina) mucronata (Neugeboren) and Nodosaria prismatica Reuss of the list are completely broken and badly preserved so they have been left as indeterminate fragments of Lingulina, Dentalina and Nodosaria, respectively. Six other species have been left in open nomenclature (Dentalina sp., Frondicularia sp., Marginulina sp., Nodosaria sp., Planularia sp. and Ramulina sp.).

The other groups represented are the Order Buliminida, Superfamily Cassidulinacea, the Order Robertinida, Superfamily Ceratobuliminacea, the Order Rotaliida, Superfamily Discorbacea, and the Order Globigerinida, Superfamily Hedbergellacea. Although only a few species have been identified in all these groups there are a significant number of specimens, especially in the case of the Hedbergellacea [Hedbergella infracretacea (Glaessner)] and Discorbacea [Gavelinella intermedia (Berthelin)].

The material under the names Clavulina angularis d'Orbigny, Polymorphina communis d'Orbigny, Polymorphina sosoria var. cuspidata Brady and the specimens of Reophax scorpiurus Montfort of the Buckinghamshire County Museum, are here considered as incertae sedis.

A brief and quick analysis of the composition of the assemblages in the Gault at Ford shows that in number of specimens, the dominant species is Hedbergella infracretacea (Glaessner). Gavelinella intermedia (Berthelin) is also abundant. Among the Nodosariida, Vaginulina recta Reuss and Lenticulina gaultina (Berthelin) are the commonest species. Arenobulimina chapmani Cushman, Spiroplectinata annectens (Parker \& Jones) 
Order Astrorhizida

Superfamily Ammodiscacea

\begin{tabular}{|l|l|}
\hline $\begin{array}{l}\text { Ammodiscus retaceus (Reuss, 1845) } \\
\text { Pl. 1. fig. 2. }\end{array}$ & p.p. Ammodiscus incertus (d'Orbigny), 1 \\
\hline $\begin{array}{l}\text { Thurammina sp. } \\
\text { Pl. 1. fig. 1 }\end{array}$ & $\begin{array}{l}\text { p.p. Thurammina alhicans Brady. } 2 \\
\text { Thurammina papillata } \text { Brady* }\end{array}$ \\
\hline
\end{tabular}

Pl. l. fig

Order Lituolida

Superfamily Lituolaxea

Bigertna." arperula (Chapman, 1896) Sagrina asperula Chapman

Pl. 1. fig. 9

Haplophragmoides nonioninotdes (Reuss,

Reophar sp.

Pl. 1. fig. 18

Textuluria chapmani Lalicker, 1935

Pl. 1 . fig. 8

Texiuluria minuta Berthelin. 1880

Pl. 1. fig. ?

Haplostiche? sherborni Chapman. 1892

PI. 1, fig. 4

Discorbina rugosa (d'Orbigny)

Haplophragmium acutidorsatum Hantk

p.p. Reophax scorpiurus Montfort, 3

p.p. Nodosaria (D.) consobrina (Orb.) 4

p.p. Textularia conica d'Orbigny, 5

p.p. Textularia praelonga Reuss, 6

Textularia minuta Berthelin

Haplostiche sherborni Chapman

\section{Superfamily Ataxophragmiacea}

Arenobulimina chapman

Cushman. 1936

Pl. 1. fig. 17

Dorothia iurris (d' Orbigny. 1840)

Pl. 1. fig. 6

Eggerellina mariae Ten Dam. 1950

P] 1, fig. 16

Gaudrina dispansa Chapman, 1892

Pl. 1. fig. 11

Gaudrina gradata Berthelin, 1880

P1. 1, fig. 12

\begin{tabular}{|l|l|} 
& $\begin{array}{l}\text { Textularia gramen d'Orbigny* } \\
\text { p.p. Textularia praelonga Reuss, 6 }\end{array}$ \\
\hline $\begin{array}{l}\text { Spiroplectinafa annectens } \\
\text { (Parker \& Jones, 1863) } \\
\text { P1. 1, fig. 5 }\end{array}$ & $\begin{array}{l}\text { Spiroplecta annectens (Parker \& Jones) } \\
\text { Spiroplecta complanata (Reuss) } \\
\text { Textularia complanata (Reuss) }\end{array}$ \\
\hline $\begin{array}{l}\text { Tritaxia pyramidata Reuss. 1863 } \\
\text { Pl. 1, fig. 13. }\end{array}$ & $\begin{array}{l}\text { Tritaxia pyramidata Reuss } \\
\text { Tritaxia tricarinata Reuss } \\
\text { Verneuilina triquetra (Münster) }\end{array}$ \\
\hline $\begin{array}{l}\text { Trochammina concava Chapman. 1892 } \\
\text { P1.1. fig. 23a-c. }\end{array}$ & Trochammina concava Chapman* \\
\hline
\end{tabular}

PI. 1. fig. 23a-c.

\section{Order Miliolida}

Superfamily Nubeculariacea

Cornuspira cretacea (Reuss, 1845) T.p. Ammodiscus incerfus (d'Orbigny), 1

P1. 1. tig. 22

Nodobacularia nodulosa $\quad$ Nubecularia nodulosa Chapman

(Chapman, 1891) Pl. 1, fig 10.

\begin{tabular}{|l|l} 
Nubecularia." depressa Chapman, 1891 & Nuhecularia depressa Chapman*
\end{tabular}

P1.. 1, fig. 21

Nubeculinella? ip.

Pl. I, fig. 15 . Nubecularia tibia (Jones \& Parker)*

\section{Superfamily Miliolacea}

\begin{tabular}{|l|l}
\hline Quinqueloculina antiqua (Franke, 1928) & Miliolina ferussacii (d'Orbigny)
\end{tabular} P1. 1. fig 14

Spiroloculina cretacea Reuss, 1854

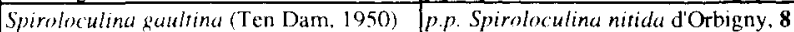

PI. 1. fig. 19

\section{Order Nodosariida}

Superfamily Nodosariacea

Astacolus tripleura Reuss, 1860

Pl. 2.fig. 1

Citharinella didyma (Berthelin, 1880)

Pl. 2, fig. 2 Miliolina tricarinata (d'Orbigny) Miliolina venusta (Karrer)

Spiroloculina asperula Karrer* p.p. Spiroloculina nitida d'Orbigny, 8

Bulimina affinis d'Orbigny

Bulimina obtusa d'Orbigny

Bulimina murchisoniana d'Orbigny

taria trochus d'Orbigny

D.p. Textularia conica d'Orbigny, 7

mina brevis d'Orbigny

not identified

Cristellaria latifrons Brady *

Cristellaria tripleura Reuss*

Frondicularia didima Berthelin*

Frondicularia perovata Chapman
Flabellina didyma (Berhelin)*
Dentulina debilis (Berthelin, 1880)

Pl. 2, fig. 3.

Dentalina distincta Reuss, 1860

P1. 2, fig. 4.

Dentalina gracilis (d'Orbigny, 1840)

Pl. 2, fig. 11

Dentalina legumen (Reuss, 1845

Pl. 2, fig. 8.

Dentalina pseudonana Ten Dam, 1950

Pl. 2, fig. 10

Dentalina pulchella (Chapman. 1893)

P1. 2, fig. 7 .

Dentalina sp aff $D$ intercellularis

(Brady. 1881) $\quad$ Pl. 2, fig. 13

Dentalina sp.

PI. 2, fig. 21

Frondicularia denticulocarinata

Chapman, 1894 Pl. 2. fig. 14

Frondicularia gaultina Reuss, 1860

Pl. 2, fig. 9.

Frondicularia pinnaeformis

Chapman, 1894 Pl. 2, f. 6

Frondicularia planifolia Chapman, 1894 PI. 2, fig 5

Marginulina debilis Berthelin

Marginulina linearis Reus:

Nodosaria (G.) cylindracea Reuss

Nodosaria (D.) cylindroides Reus.

Nodosaria (D.) hamulifera Reuss

Nodosaria (D.) lornetana (d'Orbigny)

Nodosarta (D. ) soluta (Reuss)

Nodosaria (D.) xiphiondes Reuss

p.p. N. (D.) communis d'Orbigny, 9

p.p. Nodosaria $(D$ ) farcimen Reuss, 10

Nodosaria (D.) gracilis (d'Orbigny)

p.p.N. (D. consobrina (d'Orbigny), 11

Marginulina folkestoniensis Chapman* Nodosaria (D.) legumen Reuss

Nodosaria (D.) roemeri (Neugcboren)

Nodosaria (D.) soluta (Reuss) var pulchella Chapman

Nodosaria (D.) intercellularis Brady

Nodosaria (D.) rartstriata Chapman

Nodosaria (D.) pauperata d'Orbigny

D.P. Nodosaria (D.) farcimen Reuss, 10

Frondicularia denticulocarinata

Chapman

Frondicularia gaultina Reuss

Frondicularia fritschi Reuss

Frondicularia cordai Reuss

Frondicularia guesfalica Reuss

Frondicularia microdisca Reuss

Frondicularia parkeri Reuss

Frondicularia planifolia Chapman

Frondicularia ungeri Reuss

Frondiculuria sp.

Pl. 2, fig. 12

Lagena apiculata (Reuss. 1851)

Pl. 2, fig. 16.

Frondicularia cf. strigillata Reuss

Lagena aff hispida Reuss, 1863

PI. 2, fig. 15.

Lenticulina circumcidanea (Berthelin

1880) Pl. 2, fig. 17

Lenticulina diademata (Berthelin, 1880)

Pl. 2, fig. 18

Lenticulina gaultina (Berthelin, 1880)

P1. 2, fig. 20.

Lagena apiculata Reuss

Lagena apiculata var. emaciata Reuss

p.p. Lagena hispida Reuss, 12

Lagena gracillima (Seguenza)

p.p. Lagena hispida Reuss, 13

Cristellaria circumcidanea Berthelin

Cristellaria diademata Berthelin

Cristellaria gaultina Berthelin

Cristellaria gibba d'Orbigny

Cristellaria mamilligera Karter*

Cristellaria rotulata (Lamarck)

C. rotulata (L.) var. macrodiscus Reuss

Cristellaria sternalis Berthelin

Cristellaria turgidula Reuss

\begin{tabular}{|l|l|l|l|l}
\hline Lenticulina turgidula (Reuss, 1863) & Cristellaria convergens Bornemann
\end{tabular}

Pl. 2. fig. 19

Cristellaria lobata (Costa)

Cristellara sulcifera Reuss

Lingulina loni Berthelin, 1880

Pl. 2, fig. 22

Lingulina semiornata Reuss, 1863

Pl. 2, fig. 23

Marginulina inaequalis Reuss, 1860

Frondicularia loni Berthelin

Pl. 2, fig. 24

Lingulina semiornata Reuss

Cristellaria humilis Reuss

Marginulina glabra d'Orbigny

Marginulina inaequalis Reuss

\begin{tabular}{|l|l}
\hline Marginulina jonesi (Reuss, 1863) & Marginulina cequivoca Reuss
\end{tabular}

Pl. 3, fig. 1.

Marginulina linearis (Reuss, 1863)

Pl. 3, fig. 2.

Marginulina jonesi Reuss

Cristellaria linearis Reuss*

Marginulina striatocostata (Reuss, 1863) Marginulina striatocostata Reuss

Pl. 3, fig. 3

Table 3. Left column: updated names used in this work. Right column: list of Hollis and Neaverson. Footnote explanations at end of table 
Table 3 continued

\begin{tabular}{|c|c|}
\hline $\begin{array}{l}\text { Marginulina sp. } \\
\text { Pl. 3, fig. } 4 .\end{array}$ & Cristellaria exilis Reuss \\
\hline $\begin{array}{l}\text { Nodosaria cf. affinis Reuss, } 1845 \\
\text { Pl. 3, fig. } 5 \text {. } \\
\end{array}$ & p.p. Nodosaria arthopleura Reuss, 14 \\
\hline $\begin{array}{l}\text { Nodosaria cf. bambusa Chapman, } 1893 \\
\mathrm{Pl}, 3 \text {, fig. } 8 \text {. }\end{array}$ & Nodosaria bambuia Chapman \\
\hline $\begin{array}{l}\text { Nodosaria fontannesi (Berthelin, 1880) } \\
\text { Pl 3, fig. } 6 \text {. }\end{array}$ & $\begin{array}{l}\text { Nodosaria (D.) fontannesi (Berthelin) } \\
\text { Nodosaria inflata Reuss* }\end{array}$ \\
\hline $\begin{array}{l}\text { Nodoraria obscura Reuss, } 1845 \\
\text { P1 3, fig. } 10 .\end{array}$ & Nodosaria (D.) obscura Reuss \\
\hline $\begin{array}{l}\text { Nodosaria orthopleura Reuss. } 1863 \\
\text { Pl 3, fig. }\end{array}$ & $\begin{array}{l}\text { Nodosaria tetragona Reuss } \\
\text { p.p. Nodosaria orthopleura Reuss, } 14\end{array}$ \\
\hline $\begin{array}{l}\text { Nodosaria paupercula } \text { Reuss, } 1845 \\
\text { Pl. 3, fig. } 13 \text {. }\end{array}$ & Nodosaria (D.) paupercula Reuss \\
\hline $\begin{array}{l}\text { Nodosaria sceptrum Reuss, } 1863 \\
\text { Pl. 3, fig. } 19\end{array}$ & Nodosaria sceptrum Reuss \\
\hline $\begin{array}{l}\text { Nodosaria sp. } \\
\text { Pl, 3, fig } 9 .\end{array}$ & Nodosaria $(D$.$) tenuicosta Reuss$ \\
\hline $\begin{array}{l}\text { Planularia bradyana (Chapman, 1894) } \\
\text { PI. 3, fig. } 11 \text {. }\end{array}$ & $\begin{array}{l}\text { Cristellaria bradyana Chapman } \\
\text { p.p. Cristellaria complanata Reuss, } 15\end{array}$ \\
\hline $\begin{array}{l}\text { Planularia cf priceana (Chapman, 1894) } \\
\text { Pl. 3, fig. 14. }\end{array}$ & Vaginulina priceana Chapman \\
\hline $\begin{array}{l}\text { Planularia vestita (Berthelin, 1880) } \\
\text { Pl. 3, fig. 15. }\end{array}$ & $\begin{array}{l}\text { Cristellaria bononiensis Berthelin } \\
\text { Cristellaria vestita Berthelin }\end{array}$ \\
\hline $\begin{array}{l}\text { Planularia sp. } \\
\text { Pl. 3, fig. } 16 .\end{array}$ & $\begin{array}{l}\text { p.p. Cristellaria complanata Reuss, } 16 \\
\text { p.p. Cristellaria crepidula (F. \& M.), } 17\end{array}$ \\
\hline $\begin{array}{l}\text { Preadonodosaria mutabilis (Reuss, 1863) } \\
\text { P!. 3. fig. } 12 \text {. }\end{array}$ & $\begin{array}{l}\text { Nodosaria (G.) laevigata d'Orbigny* } \\
\text { Nodosaria (G.) mutabilis (Reuss) } \\
\text { Nodonaria calomorpha Reuss } \\
\text { Nodosaria radicula (L.) var jonesi R. } \\
\text { Nodosaria }(G \text {.) humilis Römer } \\
\end{array}$ \\
\hline $\begin{array}{l}\text { Saracenaria navicula (d'Orbigny, 1840) } \\
\text { Pl. 3, fig, } 17 \text {. }\end{array}$ & $\begin{array}{l}\text { Cristellaria italica (Defrance) } \\
\text { Cristellaria navicula d'Orbigny }\end{array}$ \\
\hline $\begin{array}{l}\begin{array}{l}\text { Saracenaria triangularis } \\
\text { (d'Orbigny, 1840) }\end{array} \\
\text { Pl. 3, fig. } 18 .\end{array}$ & Cristellaria triangularis d'Orbigny \\
\hline $\begin{array}{l}\text { Tristix excavatum (Reuss, } 1863 \text { ) } \\
\text { Pl. 3. fig. } 24 .\end{array}$ & $\begin{array}{l}\text { Rhabdogonium excavatum Reuss } \\
\text { Rhabdogonium tricarinatum (d'Orbigny) }\end{array}$ \\
\hline $\begin{array}{l}\text { Tristix gaultina Khan. } 1950 \\
\text { Pi 3, fig. } 26 \text {. }\end{array}$ & not identified \\
\hline $\begin{array}{l}\text { Vaginulina gaultina Berthelin, } 1880 \\
\text { Pl. 3, fig. 21. }\end{array}$ & Vaginulina gaultina Berthelin \\
\hline $\begin{array}{l}\text { Vaginulina humilss (Reuss, } 1863 \text { ) } \\
\text { PI. 3, fig. } 23 \text {. }\end{array}$ & $\begin{array}{l}\text { Cristellaria scitula Berthelin } \\
\text { Vaginulina biochei Berthelin } \\
\text { p.p. Cristellaria crepidula (F. \& M.) } 17\end{array}$ \\
\hline \begin{tabular}{|l}
$\begin{array}{ll}\text { Vaginulina mediocarinata } \\
\text { Ten Dam, } 1950 & \text { Pl. 3, fig. } 22 .\end{array}$
\end{tabular} & $\begin{array}{l}\text { Vaginulina recta var. tenuistriata Chap. } \\
\text { Vaginulina strigillata (Reuss) }\end{array}$ \\
\hline $\begin{array}{l}\text { Vaginulina parallela (Reuss. 1863) } \\
\text { Pl. 3. fig. } 25 \text {. }\end{array}$ & $\begin{array}{l}\text { Cristellaria parallela (Reuss) } \\
\text { Cristellaria trunculata Berthelin }\end{array}$ \\
\hline $\begin{array}{l}\text { Vaginulina recta Reuss, } 1863 \\
\text { P1. 3, fig. } 20 .\end{array}$ & $\begin{array}{l}\text { Vaginulina arguta Reuss* } \\
\text { Vaginulina recta Reuss } \\
\text { Vaginulina truncata Reuss } \\
\text { V. truncata var. robusta B. \& C.* }\end{array}$ \\
\hline \multicolumn{2}{|l|}{ Superfamily Polymorphinacea } \\
\hline $\begin{array}{l}\text { Globulina lacrima (Reuss, } 1845 \text { ) } \\
\text { fitulose form. Pl. 4, fig. } 1 .\end{array}$ & $\begin{array}{l}\text { Polymorphina gibba d'Otbigny* } \\
\text { p.p. Polymorphina fusiformis (Röm.). } 18\end{array}$ \\
\hline $\begin{array}{l}\text { Pyrulina aff. bucculenta (Berthelin, 1880) } \\
\text { fistulose form } \\
\text { P] 4. fig. 3. }\end{array}$ & $\begin{array}{l}\text { Polvmorphina lactea (Walker)* } \\
\text { Polymorphina sosoria Reuss* } \\
\text { p.p. Polymorphina fusiformi. (Röm.), } 18\end{array}$ \\
\hline $\begin{array}{l}\text { Pyrulina obrusa (Reuss, } 1863 \text { ) } \\
\text { Pl. 4. fig. } 4 .\end{array}$ & $\begin{array}{l}\text { Polymorphina angusta Egger* } \\
\text { Polymorphina compressa d'Orbigny* } \\
\text { p.p.Polymorphina fusiformis (Röm.), } 18\end{array}$ \\
\hline \multicolumn{2}{|l|}{ Form Genera } \\
\hline $\begin{array}{l}\text { Ramulina aculeata (d'Orbigny, 1840) } \\
\text { Pl. 4, fig. } 9 .\end{array}$ & $\begin{array}{l}\text { Nodosaria hispida d'Orbigny } \\
\text { p.p. Ramulina globulifera Brady/R. } \\
\text { aculeala Wright, } \mathbf{1 9}, \mathbf{2 0}\end{array}$ \\
\hline $\begin{array}{l}\text { Ramulina aptienvis Bartenstein \& Brand, } \\
1951 \quad \text { Pl. 4, fig. } 2 \text {. }\end{array}$ & $\begin{array}{l}\text { p.p. Ramulina globulifera Brady, } 19.21 \\
\text { p.p. Ramulina aculeata Wright }\end{array}$ \\
\hline $\begin{array}{l}\text { Ramulina fusiformis Khan, } 1950 \\
\text { P1. 4, fig. } 5 \text {. }\end{array}$ & $\begin{array}{l}\text { p.p. Ramulina globulifera Brady, 19,22 } \\
\text { p.p. Ramulina aculeata Wright }\end{array}$ \\
\hline
\end{tabular}

\begin{tabular}{|c|c|}
\hline $\begin{array}{l}\text { Rumulina aff, globo-tubulosa } \\
\begin{array}{ll}\text { Cushman, } 1938 & \text { Pl. 4. fig. } 7 \\
\end{array}\end{array}$ & $\begin{array}{l}\text { p.p. Ramulina globulifera Brady, } 19,21 \\
\text { p.p. Ramulina aculeata Wrighe }\end{array}$ \\
\hline $\begin{array}{l}\text { Ramulina aff. laevis Jones. } 1875 \\
\text { Pl 4. fig. } 10 \text {. }\end{array}$ & $\begin{array}{l}\text { p.p. Rumulina glohulifera Brady, 19,21 } \\
\text { p.p. Ramulina aculeata Wright }\end{array}$ \\
\hline $\begin{array}{l}\text { Ramulina muricatinu l oeblich \& Tappan. } \\
1949 \text { Pl 4, fig. } 11 \text {. }\end{array}$ & $\begin{array}{l}\text { p.p. Ramulina globulifera Brady. } 19.23 \\
\text { p.p. Ramulina aculeata Wright }\end{array}$ \\
\hline $\begin{array}{l}\text { Ramulina sp. } \\
\text { Pl. } 4, \text { fig. } 8 .\end{array}$ & $\begin{array}{l}\text { Lagena giohosa (Montague) } \\
\text { p.p.Thurummina albicans. Brady, } 24\end{array}$ \\
\hline
\end{tabular}

\section{Suborder Buliminida}

Superfamily Cassidulinacea

\begin{tabular}{|l|l}
\hline Pleurostomella harroixi Berthelin. 1880 & Pleurostomella obtusa Berthelin
\end{tabular} Pl 4, fig. 6 .

Pleurontomella reusi Berthelín, 1880 p.p. Nodosaria (D. tommunis d'Orb 9

PI. 4, fig. 12

\section{Order Robertinida}

Superfamily Ceratobuliminacea

Epistomina aff. omata (Roemer, 1841)

Pl. 4, fig. 15a-c.

Epistomina spinulifera (Reuss, 1863)

Pl. 4. fig. 14a-c.

Hoeglandina chapmani (Ten Dam, 1948) Pulvinalina caracolla (Römer)

Pl. 4, fig. 13a-c

Order Rotaliida

Superfamily Discorbacea

Gavelinella intermedia (Berthelin, 1880) Anomalina ammonoides (Reuss)

Pl. 4 , fig. $16 \mathbf{a}^{-c}$.

p.p. Nodosaru (D. jarcimen Reuss, 10

\section{Order Globigerinida}

Superfamily Hedbergellacea

Hedbergella infracretacea

\begin{tabular}{ll|l} 
(Glaessner, 1937) & Pl. 4, fig. 17a-c. & $\begin{array}{l}\text { Globigerina cretacea d'Orbigny } \\
\text { Globigerina }\end{array}$
\end{tabular}

1 Only p.p. Ammodiscus incertus (Reuss) of MM (UWA). In the slide there are three specimens, one of Ammodiscus incertus (Reuss), and two of Cornuspira cretacea (Reuss). 2 non Thurammina albicans Brady of NHM. 3 non Resphax scorpiurus Montfort of BCM. In the slide there are three specimens placed as incertue sedis in this work. 4 Only Nodosaria (D.) consobrina (d'Orbigny) of NHM. 5 non Texularia conica d'Orbigny of BCM. The specimens of BCM under this name belong to Dorothia turris (dOrbigny). 6 The specimens of Textularia praelonga Reuss of BCM belong to Textularia chapmani Lalicker and not to Gaudrina gradara Berthelin as the ones of MM (UWA). 7 Only Textularia conic a d'Orbigny of BCM. 8 p.p. Spiroloculina nitida d'Orbigny in the three collections. 9 This species was only found in MM (UWA). One of the specimens belongs to Dentalina distincta Reuss, and the other two belong to Pleurostomella barroisi Berthelin. 10 of the three specimens included in the set of MM (UWA) under this name. one belongs to Dentalina distincta Reuss, the other to Dentalina sp. and the last one to Pleurostomella harroisi Berthelin. 11 non Nodosuria (D.) consobrina (d'Orbignny) of NHM. 12 In the slide of BCM there is one specimen of Lagena apiculata (Reuss) and another that is an ostracod caparace. Also Lagena hispida Reuss of NHM 13 nom Lagena hispida Reuss of BCM and NHM. 14 Of the specimens included under this name in the slides of MM (UWA), two belong to Nodosaria cf affinis Reuss and four to Nodosaria orthopleura Reuss. 15 Only Cristellaria complanata Reuss of BCM. 16 non Cristellaria complanata Reuss of BCM. 17 The two specimens under this name of the set of BCM belong to different species. one to Planularia sp. and the other to Vaginulina humilis (Reuss). 18 The slide of Polymorphina fusiformis (Roemer) of MM (UWA) has twelve specimens. Of them, two belong to Glohulina lacrima (Reuss), three to Pyrulina aff. hucculenta (Berthelin) and seven to Pyrulina obtusa (Reuss). 19 Specimens belonging to Ramulina have been founded in the sets of BCM and MM (UWA). In the two sets the species names in the slides are $R$. aculeata Wright and $R$. globulifera Brady. The specimens are not properly arranged so it is not possible to know which specimens belong to each species in the view of Hollis and Neaverson. 20 Six specimens of BCM and four specimens of MM (UWA). 21 One specimen of MM (UWA). 22 Two specimens of BCM and five of MM (UWA). 23 Two specimens of BCM and seven of MM (UWA). 24 Only Thurammina albicans Brady of NHM. \# Abnormal specimen. * Not in original list. 


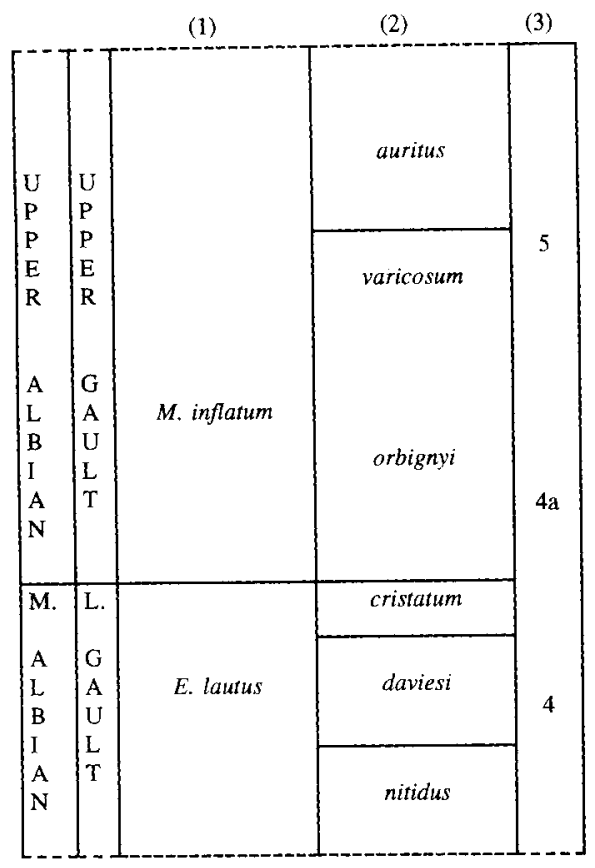

Fig. 2. Owen's $(1971,1973,1975)$ Standard ammonite zonation (columns 1 and 2) and Hart's (1973) foraminiferal zonation (column 3) at the Middle-Upper Albian boundary. Note that Hart includes the cristatum Subzone in the lautus rather than the inflatum Zone.

and Tritaxia pyramidata Reuss are the best represented among the agglutinated foraminifera and Quinqueloculina antiqua (Franke) and Spiroloculina cretacea Reuss are the commonest species of the porcelaneous group.

\section{DISCUSSION: AGE OF THE ASSEMBLAGES}

Many of the species recorded in the Phosphatic Nodule Bed of the Gault at Ford are also present in the Chapman Collection of the Gault of Folkestone (England) which has been examined in the Natural History Museum during the course of the present work (see Chapman, 1891-1898). Hollis and Neaverson (1921) pointed out that the relative abundances of the different groups were not the same for these two geographical areas. However, Waiters (1958, Unpublished Ph.D. Thesis, U.C.W. Aberystwyth) studying the foraminifera from several outcrops in Southeast England, including Folkstone, shows similar relative abundances to those at Ford. These apparently contradictory results could be due to different approaches in the procedures used to pick and count the specimens.

The recorded assemblages at Ford, which are dominated by the superfamily Nodosariacea, do not seem to be typical of the Middle Albian because in that interval the dominant group is the Superfamily Robertinacea (e.g. Hart \& Carter, 1975; Hart et al., 1981, 1989). At the same time they are not quite the same as the typical assemblages of the Upper Albian because in the upper part of the Gault Clay Formation, the fauna totally changes and becomes dominated by agglutinated taxa although nodosarids and gavelinellids are quite numerous (Hart, 1990; Talwar, 1990, Unpublished M.Sc. Thesis, U.C.W. Aberystwyth; Toogood, 1973, Unpublished M.Sc. Thesis, U.C.W. Aberystwyth).
However, looking at the stratigraphical distribution of foraminifera as seen in several key sections of southern and eastern England, Northern Ireland, northwestern Scotland and the North Sea Basin (Carter \& Hart, 1977; Hart, 1973, 1990; Hart et al., 1981, 1989, 1990) it is apparent that some of the species recorded in the Gault at Ford, such as Haplostiche? sherborni Chapman, Eggerellina mariae Ten Dam, Tritaxia pyramidata Reuss, Textularia chapmani Lalicker, Quinqueloculina antiqua (Franke), Frondicularia pinnaeformis Chapman and Vaginulina mediocarinata Ten Dam, are indicative of the Upper Albian.

The presence of Frondicularia pinnaeformis Chapman, an important zonal indicator in the Upper Albian (Carter \& Hart, 1977), in association with the typical Upper Albian Arenobulimina chapmani Cushman, Nodobacularia nodulosa (Chapman) and poorly developed specimens of Epistomina spinulifera (Reuss), characteristic of the lower Gault Clay (Hart \& Carter, 1975; Carter \& Hart, 1977; Price, 1977), points to the possibility of the Phosphatic Nodule Bed being in the Epistomina spinulifera/Frondicularia pinnaeformis Concurrent Range Zone (Zone $4 \mathrm{a}$ ) of the benthonic zonal scheme of Carter \& Hart (1977). However, the presence of Eggerellina mariae Ten Dam could indicate at least the Frondicularia pinnaeformis Assemblage Zone (Zone 5) of the same authors.

So, according to the benthonic zonal scheme proposed by Hart (1973) and Carter \& Hart (1977) it is most probable that the foraminifera of Ford were recovered from the uppermost lower Gault Clay-lower part of the upper Gault Clay, Zones $4 \mathrm{a}-$ 5 (from the uppermost Middle Albian to the lower part of the Upper Albian), equivalent to the uppermost Euhoplites lautus Zone (cristatum Subzone) to lower part of Mortoniceras inflatum Zone (orbignyi-varicosum-lowermost auritus? Subzones) of the Albian ammonite zonation (see Fig. 2).

It must be noted that Hart's treatment of the ammonite zones differs slightly from that of Owen $(1971,1973,1975)$ in that the cristatum Subzone is placed in the lautus Zone, i.e. the Middle Albian rather than the Upper Albian. Hart (1973, p. 272) comments, in relation to the Copt Point section at Folkstone, 'The cristatum Subzone contains a distintive bed of rounded nodules ... which represents a non-sequence marking the Lower-Upper Gault boundary (although the top of the cristatum Subzone is some $30 \mathrm{cms}$ above this level)'. The Ford section is therefore quite similar both lithologically and faunally to the Folkstone section.

Although Hart (1973) states that his faunal scheme, 'can, unfortunately, only be described as being of local application,' the type Albian at L'Aube, again shows a similar, major faunal change over the Middle-Upper Albian boundary (lower-upper Gault boundary). Here, as at Folkstone, the passage to the Upper Albian is marked by the appearance of Arenobulimina chapmani Cushman and Frondicularia pinnaeformis Chapman and their overlap with Epistomina spinulifera (Reuss) (see table 3 of Magniez-Jannin, 1975).

\section{ACKNOWLEDGEMENTS}

The help of Ms K. M. Hawkins of the Buckinghamshire County Museum (Aylesbury), who arranged the loan of the Hollis and Neaverson's set of specimens from that Museum and also offered helpful information on the site of the phosphatic nodules 

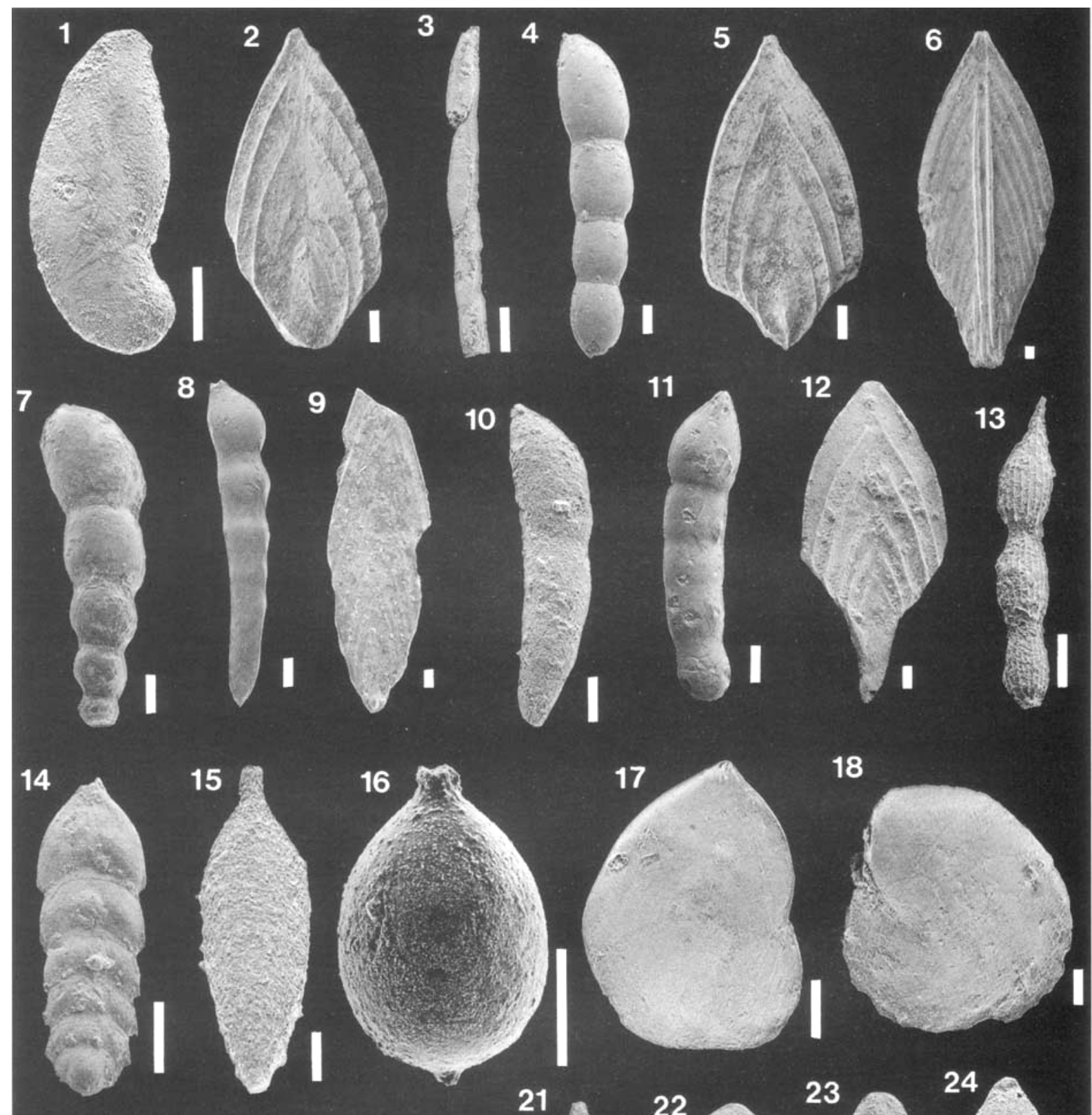

18
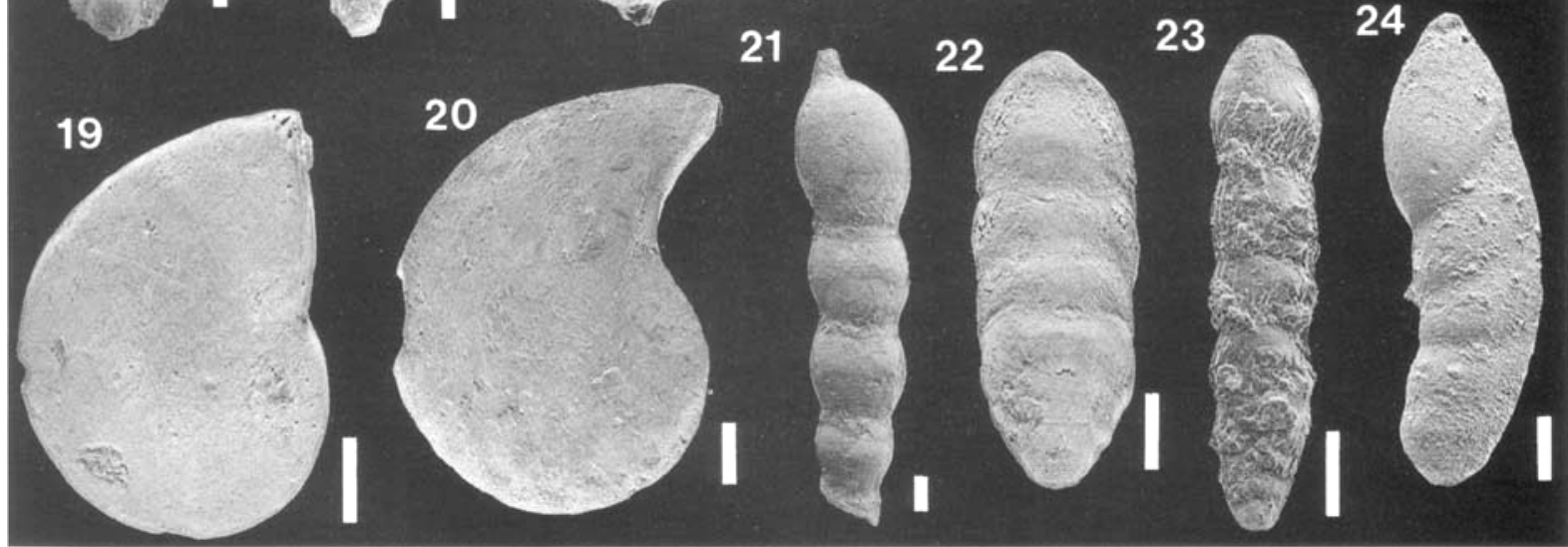

Explanation of Plate 2. Hollis and Neaverson Collection of the Gault of Ford (Buckinghamshire, England). Unless specified, all the specimens are from the Micropalacontological Museum, University of Wales (Aberystwyth), Scale bars $100 \mu \mathrm{n}$. Fig. 1. Astacolus tripleura Reuss, 1860, AYBCM. 1920.38.97.4, Buckinghamshire County Museum (Aylesbury). Fig, 2. Citharinella

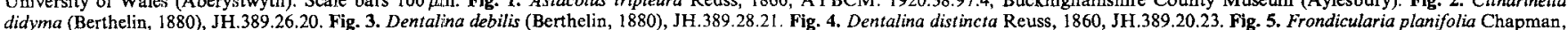

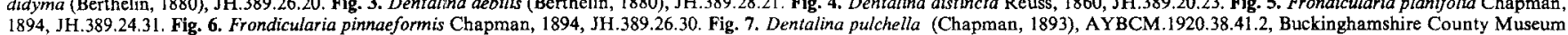

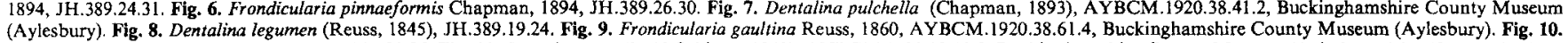

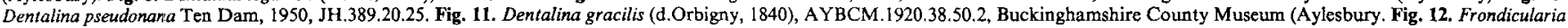
sp., JH. 389.26.32. Fig. 13. Dentalina sp. aff. D. intercellularis (Brady, 1881), JH. 389.19.26. Fig. 14. Frondicularia denticulocarinata Chapman, 1894, JH.389.25.28. Fig. 15. Lagena aff. hispida

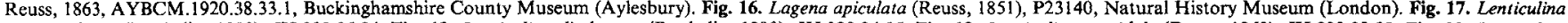

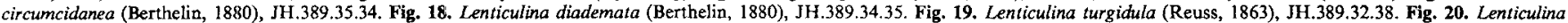

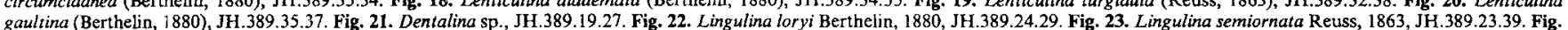
24. Marginulina inaequalis Reuss, 1860, JH.389.28.40. 


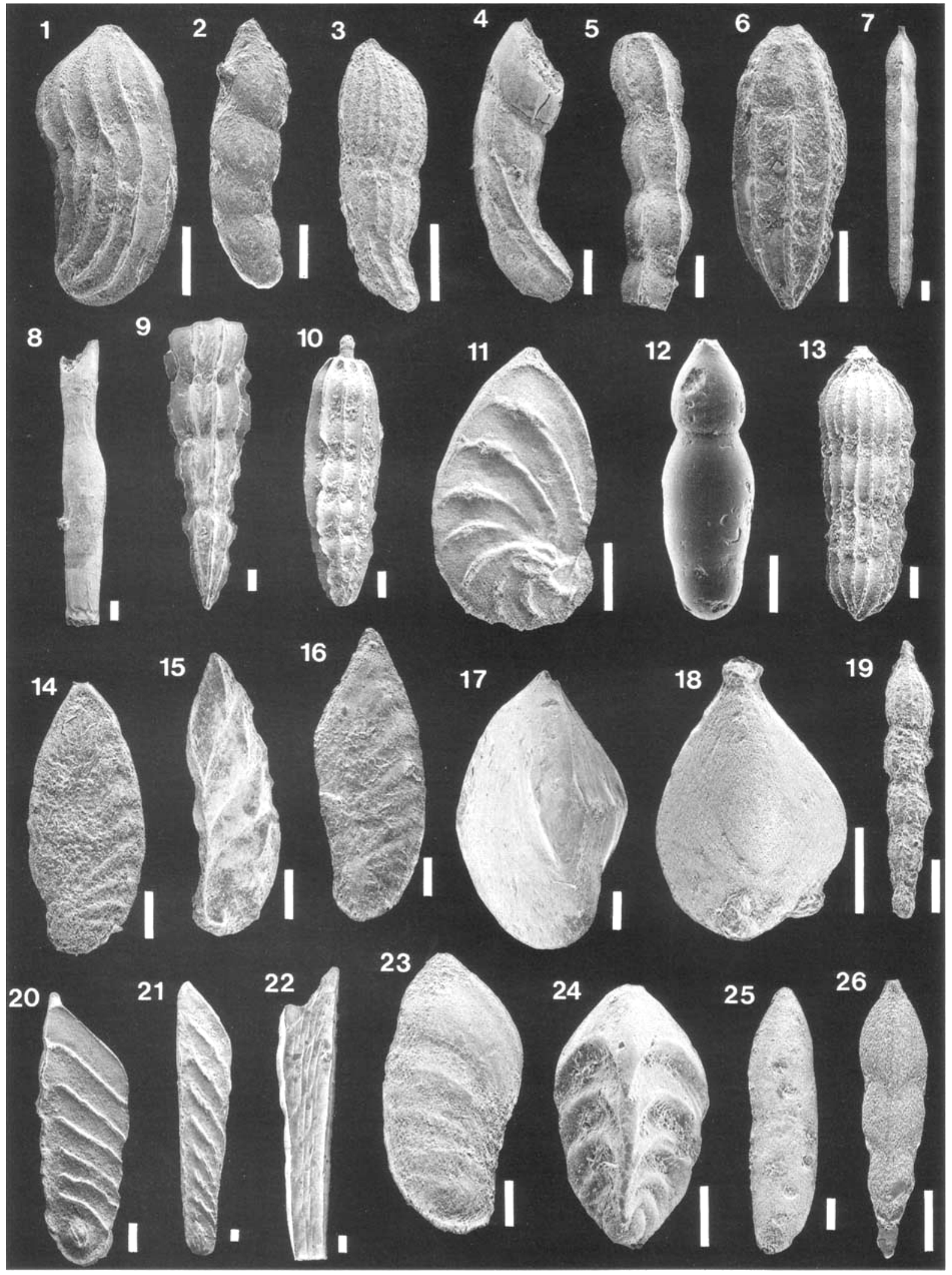

Explanation of Plate 3. Hollis and Neaverson Collection of the Gault of Ford (Buckinghamshire, England). Unless specified, all the specimens are from the Micropalaeontologica! Museum, University of Wales (Aberystwyth). Scale bars $100 \mu \mathrm{m}$. Fig. 1. Marginulina jonesi (Reuss, 1863), JH.389.28.41. Fig. 2. Marginulina linearis (Reuss, 1863), AYBCM.1920.38.38.84.1,

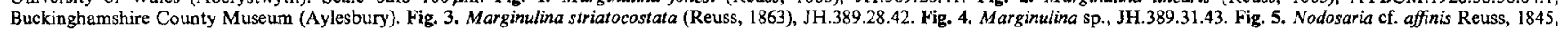

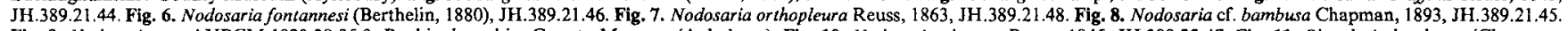
Fig. 9. Nodosaria sp., AYBCM.1920.38.35.3, Buckinghamshire County Museum (Aylesbury). Fig. 10. Nodosaria obsctura Reuss, 1845, JH.389.22.47. Fig. 11. Planularia bradyana (Chapman,

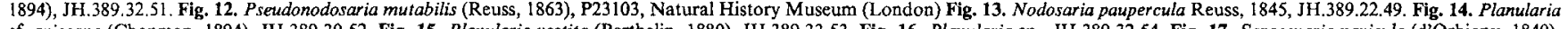

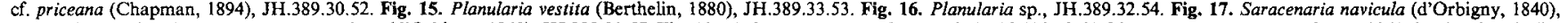

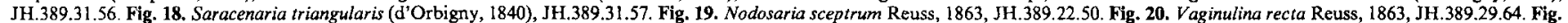

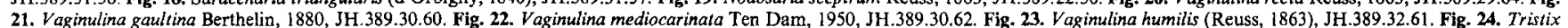
excavatum (Reuss, 1863), JH.389.27.58. Fig. 25. Vaginulina parallela (Reuss, 1863), JH.389.32.63. Fig. 26. Tristix gaultina Khan, 1950, JH.389.28.59. 


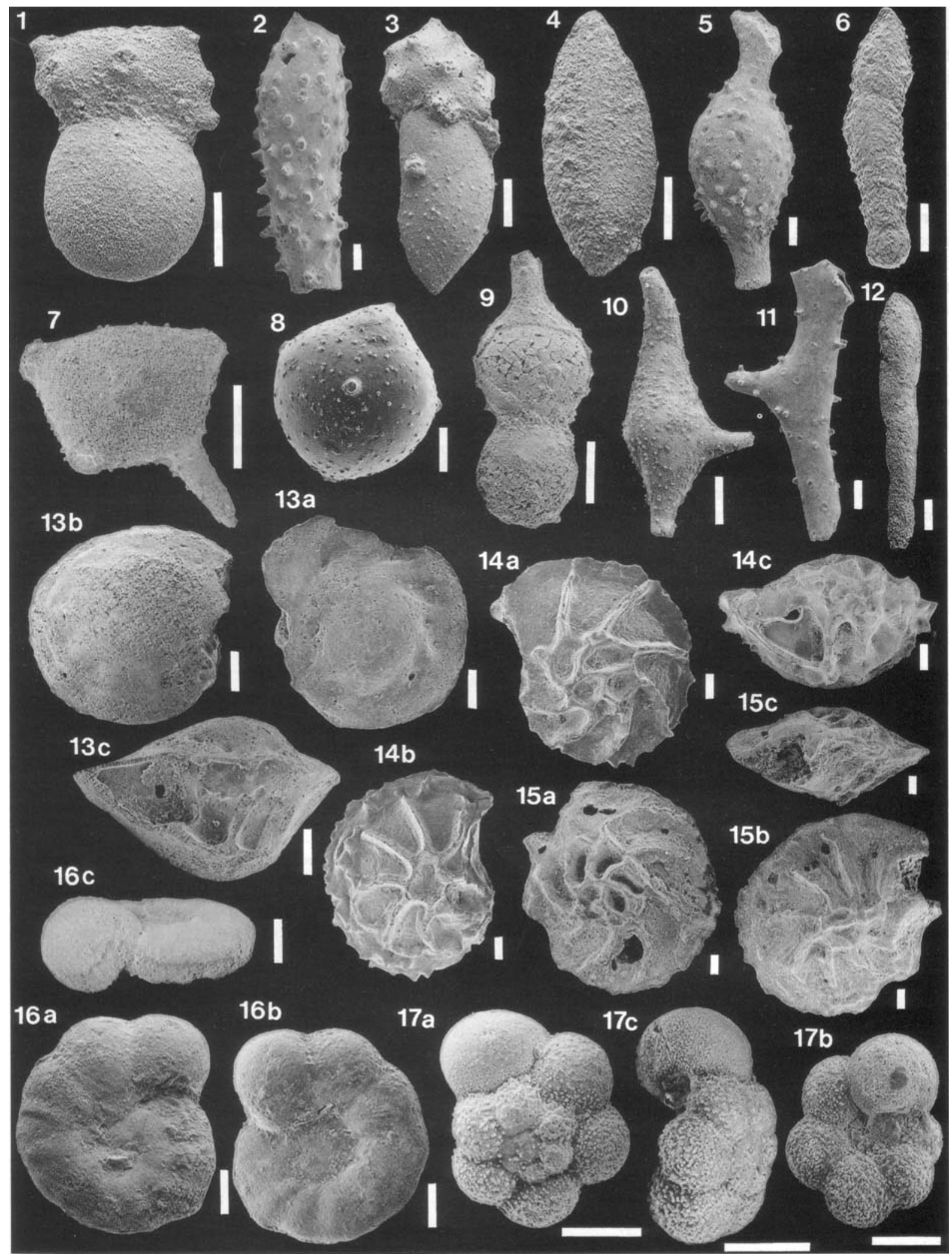

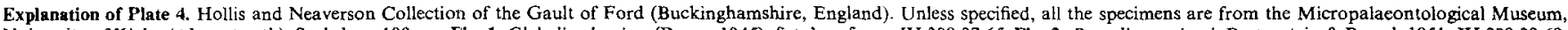
University of Waies ( $\Lambda$ berystwyth). Scale bars $100 \mu \mathrm{m}$. Fig. 1. Globulina lacrima (Reuss, 1845), fistulose form. JH.389.37.65. Fig. 2. Ramulina aptiensis Bartenstein \& Brand, 1951, JH.389.39.69.

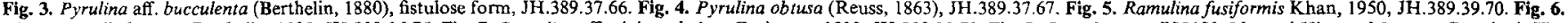

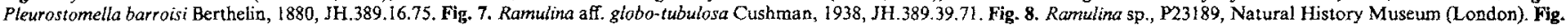

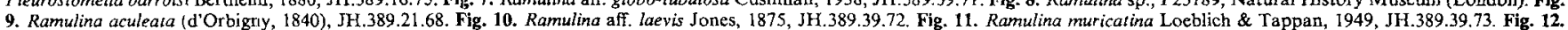

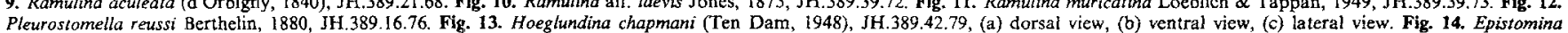

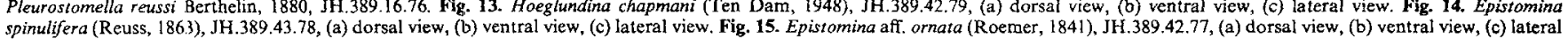

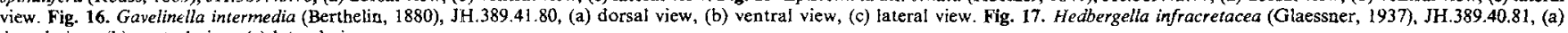
dorsal view, (b) ventral view, (c) lateral view. 
workings, is gratefully acknowledged. The first author would also like to express her gratitude to Dr John Whittaker, Mr Greg Welsh and Mr Richard Hodgkinson for their assistance and permission to examine the Gault foraminiferal collections of Hollis and Neaverson and Chapman in the Natural History Museum (London). The photographic work of $\mathrm{Mr} \mathrm{D}$. D. Griffiths (UWA) and the photographs of the specimens of the NHM provided by Dr John Whittaker are also gratefully acknowledged. This research has been partially supported by the Dirección General de Investigación Científica, Ministerio de Educación y Ciencia (Spain).

We are also indebted to Ms K. M. Hawkins for biographical details of Hollis (Curator at the Aylesbury Museum from 1908 to 1941) and to Mr I. P. Roe, Headmaster at Aylesbury Grammar School, and Prof. C. Paul of the Department of Earth Sciences at Liverpool University, for their efforts in attempting to trace the movements of Neaverson.

NB. Unfortunately, although it is clear that Neaverson was Science Master in Aylesbury Grammar School in the early 1920s and went on to become Lecturer and Senior Lecturer at Liverpool, the dates when he entered and left these institutions are as yet unknown.

Please note that the Aberystwyth Theses mentioned in the text can be obtained on loan from Hugh Owen Library (University of Wales, Aberystwyth). Also photocopies from the National Library of Wales (Aberystwyth).

\section{Manuscript received December 1994 Manuscript accepted May 1995}

\section{REFERENCES}

Carter, D. J. \& Hart, M. B. 1977. Aspects of mid-Cretaceous stratigraphical micropalaeontology. Bulletin of the British Museum (Natural History), London, Geology Series, 29: 1-135.

Chapman, F. 1891-1898. The foraminifera of the Gault of Folkstone. Journal of the Royal Microscopical Society, 1891: S65-575; 1892: 319 $330,749-758$; 1893: 579-595; 1894: 153-163, 421-427; 1896: 1-14 581-591; 1898: $1-49$.

Hart, M. B. 1973. A correlation of the macrofaunal and microfaunal zonations of the Gault Clay in South-cast England. In Casey, R. \& Rawson, P. F. (Eds) The Boreal Lower Cretaceous, Geological Journal.
Liverpool Geological Society and Manchester Geological Association, Special issue, 5: 267-288.

Hart, M. B. 1990. Cretaceous agglutinated foraminifera of the UK: A review. In Hemleben, C., Kaminski, M. A., Kuhnt, W. \& Scott, D. B. (Eds) Paleoecology, Biostratigraphy, Paleoceanography and Taxonomy of Agglutinated Foraminifera, 929-943. Kluwer, The Netherlands.

Hart, M. B. \& Carter, D. J. 1975. Some observations on the Cretaceous Foraminiferida of SE England. Journal of Foraminiferal Research, 5: 114-126.

Hart, M. B., Bailey, H. W., Fletcher, B. N., Price, R. J. \& Swiecicki, A. 1981. Cretaceous. In Jenkins, D. G. \& Murray, J. W. (Eds) Stratigraphical Atlas of Fossil Foraminifera, 149-227. 1st Edition, British Micropalaeontological Society Series. Ellis Horwood, Chichester. pp. 149-227.

Hart, M. B., Bailey, H. W., Crittenden, S., Fletcher, B. N., Price, R. J. \& Swiecicki, A. 1989. Cretaceous. In Jenkins, D, G. \& Murray, J. W. (Eds) Stratigraphical Atlas of Fossil Foraminifera, 273-371, 2nd. Edition, British Micropalaeontological Society Series. Ellis Horwood, Chichester.

Hart, M. B., Carter, D. J., Leary, P. N. \& Talwar, A. D. 1990. Agglutinated foraminiferida from the Albian/Cenomanian boundary in SE England. In Hemleben, C., Kaminski, M. A., Kuhnt, W. \& Scott, D. B. (Eds) Paleoecology, Biostratigraphy, Paleoceanography and Taxonomy of Agglutinated Foraminifera, 945-960. Kluwer, The Netherlands.

Haynes, J. R. 1981. Foraminifera. Macmillan, London, 433 pp.

Hollis, E. \& Neaverson, E. 1921. Gault foraminifera from Ford, Bucks. Naturalist, Hull, 1 July: 235-240.

Jukes-Brown, A. J. 1900. Gault and Upper Greensand (Selbornian) in Oxfordshire and Buckinghamshire. In: The Cretaceous Rocks of Britain, 1, The Gault and Upper Greensand (Selbornian) of England. Memoir of the Geological Survey, London, 1: 275-283.

Magniez-Jannin, F. 1975. Les foraminifères de l'Albien de l'Aube: paléontologie, stratigraphie, écologie. Cahiers de Paléontologie, CNRS, Paris, 358 pp.

Owen, H. G.. 1971. Middle Albian Stratigraphy in the Anglo-Paris Basin. Bulletin of the British Museum (Natural History), London, Geology Series, Suppl. 8: 1-164.

Owen, H. G. 1973. Ammonite faunal provinces in the Middle and Upper Albian and their palaeogeographical significance. In Casey, R. \& Rawson, P. F. (Eds) The Boreal Lower Cretaceous, Geological Journal. Liverpool Geological Society and Manchester Geological Association, special issue, 5: 145-154.

Owen, H. G. 1975. The stratigraphy of the Gault and Upper Greensand of the Weald. Proceedings of the Geologists' Association, 86: 475-498.

Price, R. J. 1977. The stratigraphical zonation of the Albian sediments of North-west Europe, as based on foraminifera. Proceedings of the Geologists' Association, 88: 65-91. 